\title{
A Study of Internet Chinglish under the Framework of Memetics and Its Development
}

\author{
Yuehua $\mathrm{Lu}$ \\ School of Foreign Languages and Cultures, Shanghai University of Political Science and Law, China
}

\begin{abstract}
Internet Chinglish, a product of the integration of the Internet and Chinese culture, is the most popular form of Chinglish in present-day China. The present paper has conducted a detailed study of Internet Chinglish, distinguishing it from China English, exploring the characteristics and the causes of its popularity from the perspective of Memetics, and making a prediction that Chinglish, if satisfying certain conditions, may transform to China English.
\end{abstract}

Index Terms - internet Chinglish, China English, memetics, meme, cross-cultural communication

\section{INTRODUCTION}

Thanks to the means of modern transportation and communication, the whole world community appears to be no more than a large global village, where the residents come together with different cultural backgrounds and values. Meanwhile, with the acceleration of globalization, more and more people are learning and using English. Compared with other nations, China boasts the largest number of English learners. In real-time network communication, some people, influenced by Chinese thinking mode and Chinese culture, also, owing to the lack of vocabulary or poor command of the English grammar, tend to use some expressions in English that are semantically ill-formed or incompatible with English culture, such as "stupig", "no three no four", "as far as you go to die" and so on. Such expressions are called Internet Chinglish. As a matter of fact, in recent years Chinglish is so popular that sometimesforeign media even use some Chinglish in the reports about China, in the hope of making their reports more vivid and appealing. The present paper, by taking Memetics as its theoretical foundation, carries out a detailed analysis of the characteristics and causes of Internet Chinglish, and makes a bold prediction of its developing trend.

\section{Chinglish vs. ChinA ENGLish}

To better understand Chinglish, firstly we need to make clear what China English (中国英语) is.

\section{A. Definition of China English}

As we all know, with the increasing number of people speaking English all over the world, it is inevitable that the English language has become diversified, that is, there are all kinds of varieties of English. China English is one of the English varieties with Chinese cultural characteristics, which can be regarded as comparable with the standard English.

In China, it is Ge Chuangui (1980), a famous linguist, who puts forward the concept of "China English". According to Prof. Ge, anyone other than English, should use the English language in accordance with the idiomatic usage of the English nation. However, as each nation has some unique features, there are some special things that need to be expressed when speaking or writing English. China is of no exception. Therefore, China English is an objective existence. Later, more scholars have devoted themselves into the study of China English and made great contributions.

Wang Rongpei (1991), a famous translator in China, defines China English as a kind of English with standard English as its core and Chinese features, which is uniquely used by Chinese people in China.

Another scholar, Li Wenzhong (1993) disagrees to Wang's definition, as he thinks the use of China English is not restricted to China's native land. Prof. Li offers his definition like this: China English is an English variety that has Normative English as its core. It expresses social or cultural matters specific in China in the form of lexicons, syntax and discourse by means of transliteration, loan translation, and semantic regeneration (p.19) .

The above arguments, though slightly different with each other, convey the same message that China English is a member of the family of the English language influenced by Chinese thinking modes and Chinese culture. It is difficult or even impossible to find the exact English equivalents to those China English expressions. For example, "tie fan wan" (铁饭碗) is translated as “iron rice-bowl”; “yi guo liang zhi” (一国两制) is translated as “one country, two systems". As for some unique cultural terms, they can only be expressed by transliteration, such as “kowtow” (叨头), “yamen” (衙 门), "bai hua wen" (白话文) and so on.

\section{B. Definition of Chinglish}

Chinglish, known in Chinese as "zhong shi ying yu" (中式英语), is a portmanteau of Chinese and English. As a matter of fact, Chinglish has a long history, as early as when Chinese people began to learn English. Researchers have 
noticed the existence of Chinglish and conducted numerous studies of it. Owing to the unsystematic and unsteady nature of Chinglish, scholars differ in their definitions and interpretations of Chinglish.

Deng Yanchang regards Chinglish as speech or writing in English that shows the interference of Chinese (Du \& Jiang, 2001). Some expressions are just word-for-word translation from Chinese, which do not conform to standard English usage. To understand Chinglish may not be a problem, but they are unacceptable to native speakers, because although they may be correct in grammar, the choice of words is beyond their comprehension.

Li Wenzhong (1993) defines Chinglish as a kind of misshaped English. The English learners or users in China, arbitrarily or intentionally apply the Chinese grammatical rules and idiomatic expressions to the English expressions, leading to misunderstanding among speakers(p.1).

Having been working in China as a translator for a long period of time, Pinkam (1998) points out that Chinglish is that misshapen, hybrid language that is neither English nor Chinese, but might be described as "English with Chinese characteristics".

From the above mentioned definitions, we may draw a conclusion that Chinglish is not a kind of standard but deformed English, which is shaped by the Chinese thinking mode and the influence of mother tongue. There are some examples. The Chinese idiom “bu san bu si” (不三不四) means “indecent, dubious” in English, but some people use the Chinglish "no three no four", which, if put in an English context, means "If there is no three, there is no four". As you can see, it is totally different from the original meaning. Take a look at another example: "gei ni dian yan se kan kan" (给你点颜色看看) actually means “to teach you a lesson" in English, but some people use the Chinglish "give you a little color see see", which is weird, incomprehensible and unacceptable to English native speakers.

Internet Chinglish is part of Chinglish, which originates from and spread widely on the Internet. To probe into the reason of the popularity of Internet Chinglish, first of all we need to introduce the theory of Memetics.

\section{THEORETICAL FOUNDATIONS}

\section{A. The Definition of Meme}

In 1976, a zoologist in Oxford University, Richard Dawkins, published a monograph named The Selfish Gene, in which he put forward a new term "meme". "Meme" is analogous to "gene", which is regarded as an element of cultural duplication. According to Dawkins, meme is the kind of thing that plays the same role in the process of transmitting language, ideas, beliefs, and manners as gene does in the process of biological evolution.

Inspired by Dawkin's theory, Susan Blackmore (1999), one of Dawkin's students, puts forward in her book The meme Machine that the core of memes is to imitate. Things being transmitted through imitation among human beings can be called memes, such as words, idioms, concepts, clothing, architectural styles, virus, religions and so on. Therefore, meme is the basic unit of cultural information transmission, duplicating, spreading and developing information by virtue of imitation.

Memetics, therefore, is a newly-developed theory that aims to explore the social evolution model of cultural information transmission. In the light of Darwin's Theory of Evolution, memetics also explicates cultural regulations, attempting to expound the general connection of things and the inheritance of culture.

\section{B. Features of Memes}

Richard Dawkins points out that there are three ways for measuring the quality of memes: fidelity, fecundity and longevity (Xue, 2014, 2015).

The attribute of fidelity means that memes are precisely selected. Languages, religions, and traditional customs can be handed down from generation to generation as a result of the superior fidelity. In the process of the duplication, memes generally retain the essence of previous memes instead of changing completely. The better memes replicate, the more they will remain.

Fecundity, being the most dominating attribute of memes, refers to the fast speed of transmission. The faster the speed is, the wider the scope of spreading is. Memes generate the characteristics of uniformity and disparity after the spread.

Memes can be retained lastingly on paper or in people's mind, which reveals its attribute of longevity. Longevity of memes is deemed as an essential feature of memes, without which language, culture and thoughts are not able to exist. The longevity of memes is just like the reproduction of life that has been executed through successive generations.

Blackmore points out that memes burden the huge pressure of choices in the process of evolution and there are only a limited number of memes that can be copied successfully from one head to another (Yang, 2007). Therefore, memes are divided into two types, namely, strong memes and weak memes, the former being involved in wide-ranging duplication with little hindrance and full of vitality while the latter being so impotent and unabiding that are easily forgotten by people. Heylighten (1999) holds that the realistic way of being successful memes is to see whether they can satisfy or stand the least of the selection criterion of general formalization.

\section{FoRMATION OF INTERNET CHINGLISH UNDER THE FRAMEWORK OF MEMETICS}

As is mentioned in the introductory part, Chinglish has become more and more popular on the Internet in China. 
Through analyzing a great number of Chinglish words, we've found that the theory of Memetics can well explain the formation of those words.

The first way is affixation, which means to add a prefix or a suffix or even both to the root. For example, the word "ungelivable" is widely accepted by net friends, which expresses an upset feeling that a specific person or a matter failed to live up to the speaker's expectation. As a matter of fact, "geili" is a Chinese word often used by Northeastern residents. The unknown smart netizens borrowed "geili" from Chinese, and then added the suffix "able" to it, making it an adjective "geilivable", meaning being supportive, wonderful or splendid. As the English prefix "un-" conveys the meaning "not", netizens therefore add "un-" to "geilivable", showing the opposite meaning of "geilivable", which expresses a kind of disappointment or disapproval. Trough assimilation or duplication, more and more similar words appeared.The following table presents more examples.

\begin{tabular}{|c|c|c|c|}
\hline Affixes & Word Formation & Words & Meaning \\
\hline -bility & niu + bility & niubility & awesome, remarkable \\
\hline -bility & sha + bility & shability & foolish, stupid \\
\hline -bility & zhuang + bility & zhuangbility & pretentious, artificial \\
\hline -able & geli +able & gelivable & supportive, wonderful \\
\hline un; -able & un+kao +able & unkaoable & unreliable \\
\hline un; -able & un+ding +able & undingable & being unable to stand up \\
\hline -ache & egg + ache & eggache & boring, incapable \\
\hline
\end{tabular}

The second way of formation is blending, which means to combine part of one word with part of another word, or part of one word with another complete word. "Chinglish" is a typical example, in which the first part "Chin" is taken from "Chinese" while the rest part "glish" is from "English". Therefore, the meaning of "Chinglish" is "English expressed in a Chinese way". The method of blending does not originate from the Internet, but it has been carried forward on the Internet. For example, the Chinglish word "smilence" is combined by "smile" and "silence", meaning "smiling without saying a word". The emergence of such Internet Chinglish keeps close relationship with the hottest issues at present, and the net friends create such words for the sake of ridicule or mockery. There are more examples.

\begin{tabular}{|c|c|c|}
\hline Blended Words & Word Formation & Meaning \\
\hline antizen & ant +izen (citizen) & College students or migrant workers live together like ants. \\
\hline Chinsumer & $\begin{array}{c}\text { Chin (Chinese) } \\
+ \text { sumer(consumer) }\end{array}$ & Chinese consumers who travel abroad and spend money like water \\
\hline jokarlist & $\begin{array}{c}\text { Jok (joker) + arlist } \\
\text { (journalist) }\end{array}$ & It is used to criticize the irresponsible attitude of journalists \\
\hline sextary & $\begin{array}{c}\text { sext +tary (secretary) } \\
\text { stu (stupid) + pig }\end{array}$ & $\begin{array}{c}\text { It reflects the equivocal relationship between the female secretary } \\
\text { and the boss }\end{array}$ \\
\hline stupig & $\begin{array}{c}\text { Vege (vegetable) + teal } \\
\text { (steal) }\end{array}$ & A popular online game called "stealing vegetables" in China \\
\hline
\end{tabular}

There are also some other ways of word formation on the Internet, though not quite popular. For example, the Chinglish word"togayther" was created by embedding "gay" into the word "together", meaning the two homosexual lovers eventually become a couple. Another similar word is "propoorty", which embeds "poor" into "property", implying that in face of the high housing price we are all poor people.

Apart from words, there are also Chinglish sentences prevailing on the Internet. Those sentences are merely word-for-word translation, overlooking the order or the collocation of words in standard English and without interpreting anything. Net friends use them to entertain or ridicule in certain conversation context, which might put native English speakers totally in the dark. The following sentences are typical examples.

\begin{tabular}{|l|l|}
\hline Chinglish Sentences & Chinese Meaning \\
\hline No zuo no die. & 不作死就不会死。 \\
\hline Give you some color to see see. & 给你点颜色看看。 \\
\hline You give me stop! & 你给我站住! \\
\hline We two who and who? & 我俩谁跟谁啊! \\
\hline You can you up. & 你行你上啊! \\
\hline No wind, no waves. & 无风不起浪。 \\
\hline Want money, I have none. Want life, I have one. & 要钱没有, 要命一条。 \\
\hline
\end{tabular}

\section{Possible Causes for the Prevalence of InTernet Chinglish}

How can the Internet Chinglish enjoy such a large popularity? Apart from the impact of memes, we assume that it also has something to do with social and cultural factors. 
We assume that Memetics can account for the extensive transmission of the Internet Chinglish. By means of imitation and duplication, memes inject vitality for the blossom of language. If a language were no longer replicated, it would perish. That's also the case with Internet Chinese. Words, phrases, or sentences of Chinglish that are quickly spread and widely accepted on the Internet are the results of the functions of strong language memes. The Internet Chinglish memes transmit comprehensively as they conform to the three features of memes, namely, fidelity, fecundity and longevity.

Firstly, the Internet, being a new media platform, has a tendency of surpassing traditional media. Meanwhile, the enormous number of netizens have laid the foundation for the spread of the Internet Chinglish, making sure it can be widely spread. For instance, when the word "ungelivable" first appeared on a micro-blog on December 7, 2010, within a couple of hours, it has been transmitted thousands of times. Those net friends not only make clear its pronunciation and meaning in the first time, but also think that if they do not transmit it, they are "ungelivable". Therefore, you can see the vitality, or to use another word, longevity, is guaranteed.

Secondly, as Internet Chinglish reflects the current social reality, and also because of its unique simplicity and interest, it is warmly welcomed by netizens, making it widely replicated and highly productive. Inspired by the creation of the word "ungelivable", the netizens made up some other Chinglish words such as "unkaoable", "undingable" and so on, which has been introduced in the previous section.

Thirdly, as the Internet provides free space for transmitting all kinds of news, the Internet Chinglish is thus created based on those hot issues. Being simple and vivid, the Internet Chinglish memes are easily memorized and widely spread, not only on the internet, but also in off-line life. In our daily life, we often hear people say "ungelivable", "smilence" and the like, which shows that fidelity is guaranteed.

\section{B. Cross-cultural Communication Accounting for the Creation of Chinglish}

With the process of globalization deepening, different cultures are exchanging and integrating with each other. An increasing number of Chinese people, especially youngsters, are eager to know about the outside world. To well understand Western cultures, they have to learn English first. It's a common phenomenon that some young learners are practising English at any time and any place. Moreover, when they are speaking Chinese, they prefer to use some English words now and then. However, as Chinese is the mother tongue of those speakers, it is inevitable that they are more or less influenced by the Chinese mode of thinking and the grammatical rules of the Chinese language. Consequently, a great number of English words and sentences with Chinese characteristics are coined by netizens, some of which are appropriate to the spoken language in real-time online communication, while others of which are created deliberately in articles or reports to ridicule or satirize the reality. The integration of language is so conspicuous that the Internet Chinglish memes are regarded as a new cultural phenomenon. Therefore, the creation of the Internet Chinglish memes has never been ceased.

\section{The Internet Providing a Platform for the Spreading of Chinglish}

About two decades ago, most common people had no idea what the Internet was and they rarely had chance to make social contacts on the Internet. However, the past decade has witnessed the rapid development of the network, which, as a matter of fact, has entered every household and all walks of life. The distinct platforms like Facebook, Micro-blog, Wechat, QQ etc. are convenient tools for communication. Almost all kinds of things, communicating with friends or clients, doing online shopping, booking airplane or hotel tickets, listening to music, watching movies, to name just a few, can be satisfyingly accomplished through the Internet. The open and free Internet, which is unconstrained and exoteric, provides free space for displaying imagination and innovation, thus paving the way for the propagation of network Chinglish. To put it in other words, the virtual network is the carrier of network Chinglish memes. It is self-evident that the excellence of the network is a necessary medium for the imitation and replication of Chinglish memes. Whenever a sensational event takes place, netizens would coin fashionable network Chinglish words. In addition, the emergence of network Chinglish memes demonstrates swift and forceful power with the upgrading of computers and technology.

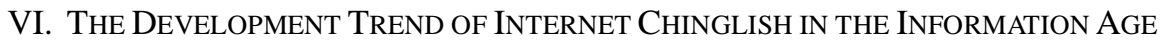

The international cultural integration and the prevalence of network culture have brought about Internet Chinglish, the so-called "age product". The combination of Internet Chinglish and specific culture and times reflects a fact that the earth has become a global village, and all kinds of cultures are infiltrating each other. Chinglish is actually a malformed product of the permeation of English and Chinese culture. Then, with the intrusion of network culture, Internet Chinglish has become more and more popular. Some people may ask: can Chinese people acquire idiomatic English? Where will Internet Chinglish head for? It is more likely that Internet Chinglish will transform to China English.

It is known to all that language is dynamic and changing all the time. A typical example, as a matter of fact, is the English language gradually becoming the dominant language in the world. Kachru, who has made great contributions to the study of India English, claims that India English derives from the hybrid English with Indian characteristics. Similarly, China English is in the expansion circle of the World English, which is being developed and changed in China. As we mentioned in the second section, there is no clear cut between China English and Chinglish, the latter being an inevitable stage in the process of the development and evolution of China English. Therefore, it is justified to 
say that the dynamic attribute of language provides the feasibility of Chinglish transforming to China English.

Secondly, seen from the perspective of Second Language Acquisition, Chinglish, though being a kind of hybrid English, is an indispensable stage of acquiring English, which is called by some researchers as an "interlanguage" between Chinese and English. Language learners have already formed a language system of their mother tongue, but in the process of learning a second language, they are sure to be influenced by their native language. However, with the time going by, their acquisition criteria and correct knowledge of English are gradually increased, so are their English learning ability and level. This change will replace the assimilation of mother tongue, and in the end, they will find a balance between their mother tongue and English.

Thirdly, perceived from the angle of cross-cultural communication, when Chinese people communicate with native speakers of English, they should respect their cultural and pragmatic rules; at the same time, native speakers of English should also take Chinese cultural and pragmatic habits into account. This is called empathy, which refers to the ability to look at problems from the perspective of others (Zhang \& Zhang, 2014). The application of empathy in cross-cultural communication can achieve better communicative effects. With the deepening of China's reform and opening-up policy, more and more foreigners come to China. When communicating with westerners, we need try to use more English expressions with Chinese characteristics, encouraging westerners to better understand Chinese culture. If the native speakers of English are more tolerant and give full play to empathy, it is possible that Chinglish would turn into China English.

Although there exist possibilities for Chinglish transforming to China English, there are some prerequisites. Firstly, and most basically, the expressions that are related to Chinese traditional and social life have no exact equivalents in English and therefore cannot be fully understood by native speakers. The second condition is that the transformation of Chinglish into China English needs to be accepted by most native speakers and the official media. Some political lexicons, for example, “three represents" (in Chinese “三个代表”), have been accepted by the western media, though "represent", originally a verb, is bearing a plural form. This deformed, hybrid Chinglish word is frequently applied in authoritative media, showing that it has been successfully transformed from Chinglish to China English.

With regard to Internet Chinglish, if the expression is a strong meme and can satisfy the previously mentioned two prerequisites, they are more likely to be acknowledged as China English; on the other hand, if it is a weak meme, most probably it will only flourish for a short period of time and then vanish out of the public's sight.

\section{CONCLUDING REMARKS}

The unique form and rich cultural background of the Chinese language is incomparable. Chinese English is an effective way to propagate the Chinese culture as well as the Chinese language, thus improving the international image of China. Chinglish, especially the Internet Chinglish, is a product of this era and is an inevitable stage of the development of China English. For language learners and users, English learning is not only about imitating pronunciation and grasping grammar rules, but is about how to disseminate Chinese culture comprehensively and accurately to the whole world.

\section{REFERENCES}

[1] Blackmore S. (1999). The Meme Machine. Oxford: Oxford University Press.

[2] Dawkins R. (1989). The Selfish Gene. Boston: Boston University Press.

[3] Du R. Q., \& Jiang Y. J. (2001). Review on the Study of "China English" in the Past Twenty Years. Foreign Language Teaching and Research, (1), 37-41.

[4] Ge C. G. (1980). On the Translation of Chinese to English. Translation Correspondence, (2), 1-8.

[5] Heylighen F. (1998). What Makes AMeme Successful? Selection Criteria for Cultural Evolution. In Ramaekers, Jena, (Eds), Proceedings Fifteenth International Congress on Cybernetics.

[6] Li W. Z. (1993). China English and Chinese English. Foreign Language Teaching and Research, (4), 18-24.

[7] Pinkham J. (2007). The Translator's Guide to Chinglish. Beijing: Foreign Language Teaching and Research Press.

[8] Wang R. P. (1991). China English Is an Objective Existence. Journal of PLA University of Foreign Languages, (1), 1-8.

[9] Xue J. J. (2014). Internet Chinglish from the Perspective of Memetics. Journal of Changjiang University, (7), 108-110.

[10] Xue J. J. (2015). Analysis of Internet Chinglish from the Perspective of Memetics and Adaptation Theory. Journal of Anyang Institute of Technology, (5), 105-107, 111.

[11] Yang J. (2007). Memetics and News Catchwords. Shangdong Foreign Language Teaching, (1), 17-21.

[12] Zhang H., \& Zhang X. L. (2014). On Possibility and Feasibility of Chinglish Transforming to Chinese English. Journal of Nanchang Institute of Technology, (5), 51-55.

Yuehua Lu was born in Yancheng, China in 1974. She received her PH. D degree in English Language and Literature from Shanghai International Studies University, China in 2018.

She is currently an associate professor in the School of Languages and Cultures, Shanghai University of Political Science and Law, Shanghai, China. Her research interests include Modern Linguistics and English teaching.

Dr. Lu is a member of Translators Association of China. 